\title{
Social Economy: the Potential and Challenges of Social Enterprises in Lithuania
}

\section{Jolita Greblikaitè}

Aleksandras Stulginskis University, Universiteto str. 10, Akademija, Kauno raj., Lithuania jolita.greblikaite@asu.lt

\section{Neringa Gerulaitienè}

Kaunas University of Technology, K. Donelaicio str. 73, Kaunas, Lithuania neringa.gerulaitiene@ktu.lt

\section{Živilè Žiukaitè}

Aleksandras Stulginskis University, Universiteto str. 10, Akademija, Kauno raj., Lithuania zivile.ziukaite@gmail.com

\section{Juan J. Garcia-Machado}

Professor of Finance, University of Huelva, Plaza de la Merced, 11. 21002 Huelva, Spain machado@uhu.es

\section{ᄃrossef} http://dx.doi.org/10.5755/j01.eis.0.11.18916

The paper analyses the peculiarieties of social economy, focusing the scientific attention to social enterprises and their environment in EU and, especially, Lithuania. The research problem of the paper lays upon revealing the situation and development of social entrepreneurship and social enterprises in EU and Lithuania, especially emphasizing rural areas and their peculiarities. The aim of the paper is to disclose the role of social economy and the importance of social enterprises in it, especially concentrating on the environment analysis for such business in Lithuanian rural areas. In the research paper, there were analysed social economy context and importance, legal, economic and social environment of social enterprises in Lithuanian rural area, and social enterprises in Lithuania in terms of latest statistical data. Main findings of the fulfilled research are following: social economy remains very important in EU countries, but the exposure of it is quite different in various countries. Lithuania is trying to implement the principals of social economy in the policy of the country. Now the attention is focused on social entrepreneurship and social enterprises as the unused potential for economy boost in the country. Environement analysis of social enterprises, especially focusing on rural areas of Lithuania, revealed that situation is getting better, but there are a lot of things to be improved for successful development of social business in the country. The improvement should start from public institutions and their focused activity to improve conditions for social enterprises. Otherwise, intentions from business actors are very important also. The further guidance of this research could lead to deeper analysis of social entrepreneurs' intentions due to starting up social business gathering primary data from the potential and existing entrepreneurs. Rural areas remain as unexplored area for social business creation, especially when additional financial support is planned for them.

KEYWORDS: social economy, social entrepreneurship, social enterprises, rural areas, Lithuania.

\section{Abstract}

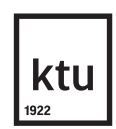

European Integration Studies No. $11 / 2017$

pp. $53-64$

DOI 10.5755/j01.eis.0.11.18916

(c) Kaunas University of Technology the Potential and Challenges of Social Enterprises in Lithuania

Submitted 04/2017

Accepted for publication 08/2017 


\section{Introduction}

\section{Social Economy in the European Union}

The actuality of the research fulfilled in the article is based on the main principles of EU functioning. The social dimension was always a priority for the Union and for the countries in it. Otherwise, social economy and social enterprises are congruent part of overall economy. Many academics analysed the phenomenon of social economy (Dunoyer, 1830; Evans \& Syrett, 2007; Arpinte, Cace \& Cojocaru, 2010; Vaillancourt, 2009; Moulaert \& Ailenei, 2005), however a universal definition of the social economy still does not exist. The characteristics of the social economy vary from country to country. The strenghetning of economy in the countries is important for them and all the entity. Social entrepreneurship and enterprises are the tool of unused potential. In some member countries, social entrepreneurship was developing more than 20 years. In other countries, in this case in Lithuania, social business just started to gain its place in the market. The other reason for researching social enterprises in Lithuania is difficulties in Lithuanian economy, especially in rural areas (Greblikaite, Rakstys, 2016). Lack of constant research in this field provides the scientific quriosity to analyse this issue in more detailed way. The research problem of the paper lays upon revealing the situation and development of social entrepreneurship and social enterprises in EU and Lithuania, especially emphasizing rural areas and their peculiarities. The aim of the paper is to disclose the role of social economy and the importance of social enterprises in it, especially concentrating on the environment analysis for such business in Lithuanian rural areas. The object of the research is social enterprises as a part of social economy. Methods of the fulfilled research are scientific literature analysis in-depth, situation analysis, statistical data analysis, comparative analysis. The originality/ value of research is related to the actuality of analysed question in Lithuanian economy and the detailed analysis of situation of the analysed object. Novelty of the research lays upon revealing obstacles and perspectives of social enterprises development in Lithuanian rural areas.

The definition of social economy first appeared in France in the XIX century (Defourny \& Develtere, 1999). The French liberal economist Charles Dunoyer (1830) published a Treatise on social economy that advocated a moral approach to economics. The French sociologist Frederic Le Play accepted and contributed this concept in socioeconomic analysis. In 1867, he introduced the term e'conomie sociale at the Universal Exhibition (Bidet, 1997). According to Topalov (1999), in Frederic Le Play's text, he defines the social economy as the study of the situation of the working class and of its relations with other classes (Moulaert \& Ailenei, 2005).

For a long time, the definition was much broader than it is today. A universally accepted definition of the social economy still does not exist, and the definition may vary from one country to another (McMurtry, 2010; Defourny \& Develtere, 1999). Social economy enterprises and organisations are present in many different forms, at different levels, local, national and European.

Many academics analysed the phenomenon of social economy (Evans \& Syrett, 2007; Arpinte, Cace \& Cojocaru, 2010; Vaillancourt, 2009). According to Defourny \& Develtere (1999), any economic phenomenon that has a social dimension, and any social phenomenon that has an economic dimension, could be considered as a part of the social economy. Social economy is everywhere and for anyone. Across the social economy are a variety of different relationships between stakeholders such as volunteers, members, trustees, users, workers, funders, customers, contractors and the wider community (Smith, 2005). The social economy includes mutual societies, cooperatives, associations, foundations, as well as new forms of social enterprises and organisations which share social economy's values (Social economy Europe, 2015). Social economy enterprises and organisations are particularly active in social security, education, social and health services, banking services, insurance services, local services, renewable energy, training and research, social tourism, consumer services, handicraft, industrial and agrifood production, 
building, residential environment and cooperative housing, associated work, as well as in the domains of culture, sport and leisure activities (Social Economy Europe, 2015).

Essentially, the social economy is made up of the voluntary, non-profit and co-operative sectors that are formally independent of the state. Their market activities are means of achieving social development goals that transcend the market per se. Thus defined, the social economy is considered as a third sector (Browne, 1997). According to the approach used by Le'vesque et al. (1999), there exists a 'third sector', different from the traditional public 'general interest serving' and the private market sectors, that combines: formal and informal elements at the level of organisation (market, state, volunteering, self-help and the domestic economy), market and nonmarket- oriented production and valorisation of goods and services, monetary and non-monetary resources at the level of funding (Moulaert \& Ailenei, 2005).

As stated by Concise (2003), the social economy is defined as the sector of economic activity made up of social enterprises organized around shared values concerned with the satisfaction of needs and not for profit principles. It is distinguished by cooperation and self-organization, distinctive types of inter-organizational relationships, and the pursuit of a new mode of production and a mode of economic integration which is characterized by norms of reciprocity, which make it both a formalized subsector of the broader third sector and distinct from the public and private sector.

CIRIEC (2000) defines the social economy according to four criteria: (a) the object of providing services to members (common or mutual interest) or the community (general interest); (b) the primacy of people over capital; (c) democratic functioning; and (d) a management system which is independent of the public authorities (Smith, 2005).

According to Vaillancourt (2009), social economy organizations produce goods and services with a clear social mission and have these ideal-type characteristics and objectives:

1) The mission is services to members and communities and nonprofit oriented.

2) Autonomous management is independent of government/ public authorities.
3) Democratic control by membership

4) People have priority over capital.

5) Participation, empowerment, individual, and collective responsibility and solidarity.

As reported by Chaves (2015), the main shared features of the social economy are:

1) They are private;

2) They are formally-organised;

3) They have autonomy of decision, meaning that they have full capacity to choose and dismiss their governing bodies and to control all their activities;

4) They have freedom of membership;

5) Any distribution of profits or surpluses among the user members, should it arise, is not proportional to the capital or to the fees contributed by the members but to their activities or transactions with the organisation.

6) They pursue an economic activity in its own right, to meet the needs of persons, households or families.

7) They are democratic organisations.

Social economy became a subject of interest because its enterprises and organisations had to assume an increasing role in the production and supply of social goods and services of public interest (Arpinte, Cace \& Cojocaru, 2010). Europe (Evans \& Syrett, 2007; Borzaga and Santuari, 2003; ECOTEC, 2000).

The Social Economy creates new quality jobs and has the capacity to meet today's challenges, not only through labour-intensive production, but also through innovative technologies. It also contributes to the social integration of vulnerable sectors of society (Social Economy Europe, 2015).

Social economy organisations continue to hold a significant potential, particularly by providing open jobs for the people belonging to vulnerable groups "goods and services that had to be 
provided at affordable cost to mainly vulnerable social groups were covered, at varying levels, by the social economy sector" (Cace et all, 2010, p 139). The period of social and economic crisis stresses the importance of the social economy sector, knowing that the loss of job or the employment opportunities affect primarily the people having a lower educational or social capital. The reintegration or insertion of these people on the labour market is more difficult, sometimes very unlikely, with high probability to remain (Arpinte, Cace \& Cojocaru, 2010).

The Social Economy is founded on the principles of solidarity and collective involvement in a process of active citizenship, individuals deciding to collaborate on a voluntary, co-operative and reciprocal basis, it generates high quality jobs and a better quality of life, and offers a framework suited to new forms of enterprise, work and responsible consumption (Social Economy Europe, 2015). Also, strong social economy initiatives are focused on community-based actions that incorporate the principles of equity, redistribution, solidarity, mutuality and meeting social needs rather than maximizing profit (Pearce, 2003). The social economy plays an important role in regional and local development and social cohesion, is socially responsible, in conducting activities, social economy actors focus on social aims, and social economy is a factor of economic democracy.

The social economy contributes to the stability and pluralism of markets, contributes to key European Union's priorities and strategic objectives, such as: smarter, sustainable and inclusive development, social cohesion, full employment and the fight against poverty, participatory democracy, better governance, sustainable development, etc. (Social Economy Europe, 2015).

On the other hand, the social economy has some weak points. Weak social economy approaches are criticized for not addressing societal transformation, minimal attention to environmental concerns (Amin et al., 2002). A critical point of differentiation is whether social economy/ enterprise activities are able to generate their own capital, rather than relying on an ongoing subsidy from the derivatives of the mainstream economy and the politics of redistribution (Connelly, Markey \& Roseland, 2011).

Social Economy enterprises and organisations are an integral part of the European social model and play an important role within the objectives of European policies, in particular for employment, social cohesion, entrepreneurial spirit, governance, local development etc., to which they actively contribute. The social economy is fast growing sector in Europe (Molloy et al., 1999). In the EU, there are around 2 million social economy entities, accounting for approximately $10-12 \%$ of all European businesses. Traditional social economy entities employed over 14.5 million people, equivalent to $6.5 \%$ of the entire EU working population in 2010, up from 11 million and $6.5 \%$ in 2002 (Liger, Stefan \& Britton, 2016). Social economy enterprises main purpose is to serve their members rather than maximise profits.

In the following chapters of the article social economy actors -social enterprises and their environment in EU and Lithuania are discussed in detail.

Situation analysis of the social enterprises and entrepreneurship environment in Lithuanian rural areas
The research of social entrepreneurship is relevant due to two groups of reasons. They could be identified as intrinsic and extrinsic reasons. Intrinsic reasons are those arising from the general economic situation both in the European Union and in Lithuania. Economy's growth rate of the EU is rising not as fast as expected, and population employment is insufficient. Competition is high. It acts as stimulus to business to look for new markets, new products or services and new models of entrepreneurship performance. Entrepreneurship problems in Lithuania are like those in other countries of the EU, and some of them are even more significant, e.g. lack of funding sources, bureaucratic obstacles, activities lacking innovation, challenges posed by small market, etc. Social entrepreneurship is one of the possible alternatives for solving these problems, and the benefit of it is undeniable.

Another group of reasons which encourages further research into social entrepreneurship is extrinsic or initiated reasons. It covers all political and other initiatives which appeared based on 
the first group of reasons, i.e. encouraging social entrepreneurship at the strategic level starting from the Lisbon Strategy 2000 and to the Entrepreneurship 2020 Action Plan at the EU level, which clearly articulates and emphasises the need for development of such entrepreneurship, establishment of social entrepreneurship and supporting social entrepreneurs. The Concept of Social Entrepreneurship in Lithuania (LR Ukio ministerija, 2015) approved in April 2015 is the most recent politically-legislative initiative in the sector of social entrepreneurship development.

For better understanding of the issues of social entrepreneurship and social enterprises in Lithuania it is worth analysing the environment of their activity (Greblikaite, Rakstys, 2016).

Legal environment. The Lithuanian government has made some steps towards development of social enterprises, social entrepreneurship, and social innovation, but the essential one has been made just in 2015. The Lithuanian government confirmed the concept of social entrepreneurship adopted in April 2015 (LR Ukio ministerija, 2015). According to the definition accepted by the Ministry of Economy, "social entrepreneurship is a business model according to which the use of market mechanism and the pursuit of profit are related to social aims and priorities. It is based on corporate social responsibility and public and private sectors' partnership. Social entrepreneurship applies social innovation. Such entrepreneurship involves three main aspects: entrepreneurial based on casual business activity, social based on social aims, and managerial based on profit sharing and fair public management."(LR Ukio ministerija, 2016, p. 3). The essence of social entrepreneurship according to the adopted concept is based on attracting existing models for this kind of business and changing NGOs activity through adapting existing business models. The concept has three objectives (LR Ukio ministerija, 2016, p. 6):

1) To create favourable legal environment for social entrepreneurship;

2) To create favourable financial and tax support system;

3) To reach the visibility and awareness of the phenomena in the society.

The Lithuanian Ministry of Economy (see www.ukmin.lt) is now consulting public entities, businesses including those in rural areas for the preparation of the Law on Social Enterprises. The consultation especially focuses on co-operation in revealing criteria for the evaluation of social entrepreneurship. In the autumn of this year some special meetings will be announced for businesses in rural areas. It will be based on supporting social entrepreneurship in rural areas. A lot of special teaching courses will be made available for businesses situated in rural areas, seeking to invite family business representatives and local action groups to participate in the upcoming meetings.

The coherence of the above-mentioned dimensions provides successful model of social enterprises operating in various countries of the EU. Social entrepreneurship is not the only and the best solution for the traditional business, but it suits the political and social model of the EU and the conditions are favourable or become favourable for the creation of such business and social enterprises. It is very important to integrate EU laws with Lithuanian legislation and specifically define what is considered a social enterprise and what criteria social business should meet.

The real actors in the Lithuanian social entrepreneurship and social business are NGOs and SMEs (see Figure 1). The social concept provides a quite similar understanding of what entities should be implementing the social mission in business or, to be more precise, create added value with very specific social dimension. But legislation regulates social services providers therefore the situation must be improved in terms of appropriate legislation.

Economic environment. To better understand the above-mentioned situation in Lithuanian rural areas, current problems should be discussed deeper. Emigration is a problem not only in Lithuanian rural areas. It is one of the biggest problems in the entire country. Lithuania has the highest emigration numbers in the EU'. There are various causes for this but the essential ones are

1 http://www.migracija.lt/index.php?1357390560 
Figure 1

Spectrum of social enterprises in Lithuania. Source: EC, 2014

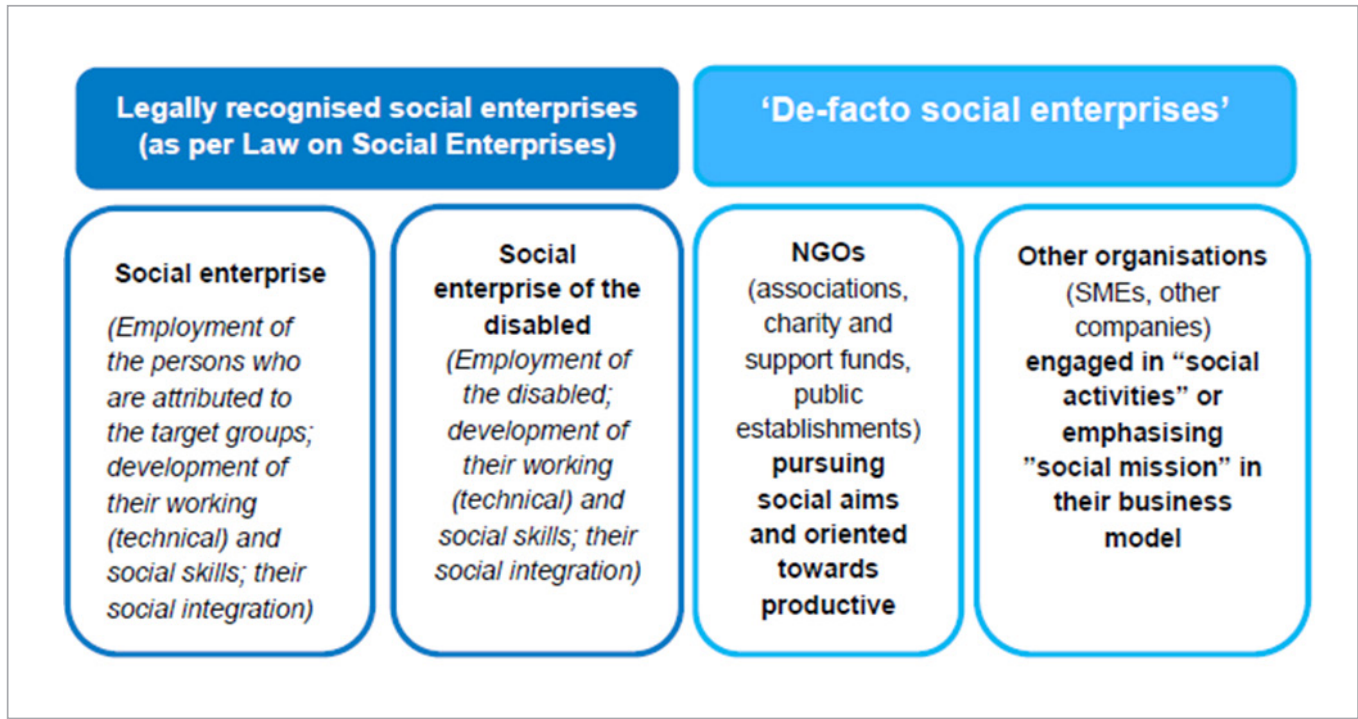

economic and social. A lack of job places in various sectors remains the most important problem in rural areas. Diversity of activities and business could theoretically provide the conditions for citizens to build their life in native country.

Social economy in the biggest EU countries is very important and creates significant amount of income for their budget. As the statistical data reveal, the United Kingdom, Germany, Spain, France, Finland experienced a boost in social economy (see Figure 2). But, for example, such countries as Denmark, Malta, Cyprus, Latvia were not interested in developing their social enterprises and boost social economy. Slovakia, Romania, Ireland, Bulgaria, Slovakia, and Lithuania were in quite analogous situation in terms of the size of their social economy (OECD, 2013).

Ney et al. (2014, p. 60; Konda et al., 2015) mention that, first, value creation refers to the design and delivery of products and services. Some social entrepreneurs will introduce entirely new practices to the provision of public goods and social services. Secondly, value creation also involves the financing practices, human resource management and marketing regimes to deliver products. Some social entrepreneurs may provide a rather common product or service, say health care, but are radically innovative in their financing, managing and marketing practices. In this way, the framework captures social innovations that create value in terms of the services or products, in terms of management and in terms of both. Social innovations aim to create value for society. In some EU countries, for example Slovenia, the greatest difficulty with the implementation of social innovation into the social setting is the weak supportive environment, lack of funds and the unwillingness of the state and other important actors to take risks and make changes (Azmat, Samaratunge, 2013). In Lithuania, the situation is quite similar, some of the key factors remain a lack of legislation, tax regulation, weak knowledge about social entrepreneurship and social innovation. Such conditions lead to insufficient development of innovative social enterprises. Unemployed people lack inspiration and support for successful entrepreneurial social start-ups.

The data reveal that the motives and preconditions for social economic activity in different countries remain different and can remain different in the future. But strong economies are generally more involved in social entrepreneurship than weaker ones. In the European countries, more than $99 \%$ of enterprises are small and medium-sized (SMEs) ones². In Lithuania, the situation is the same.

2 http://ec.europa.eu/eurostat/web/structural-business-statistics/structural-business-statistics/sme?p_p_ id=NavTreeportletprod_WAR_NavTreeportletprod_INSTANCE_vxIB58HY09rg\&p_p_lifecycle=0\&p_p_state=normal\&p_p_mode=view\&p_p_col_id=column-2\&p_p_col_pos=1\&p_p_col_count $=4$ 


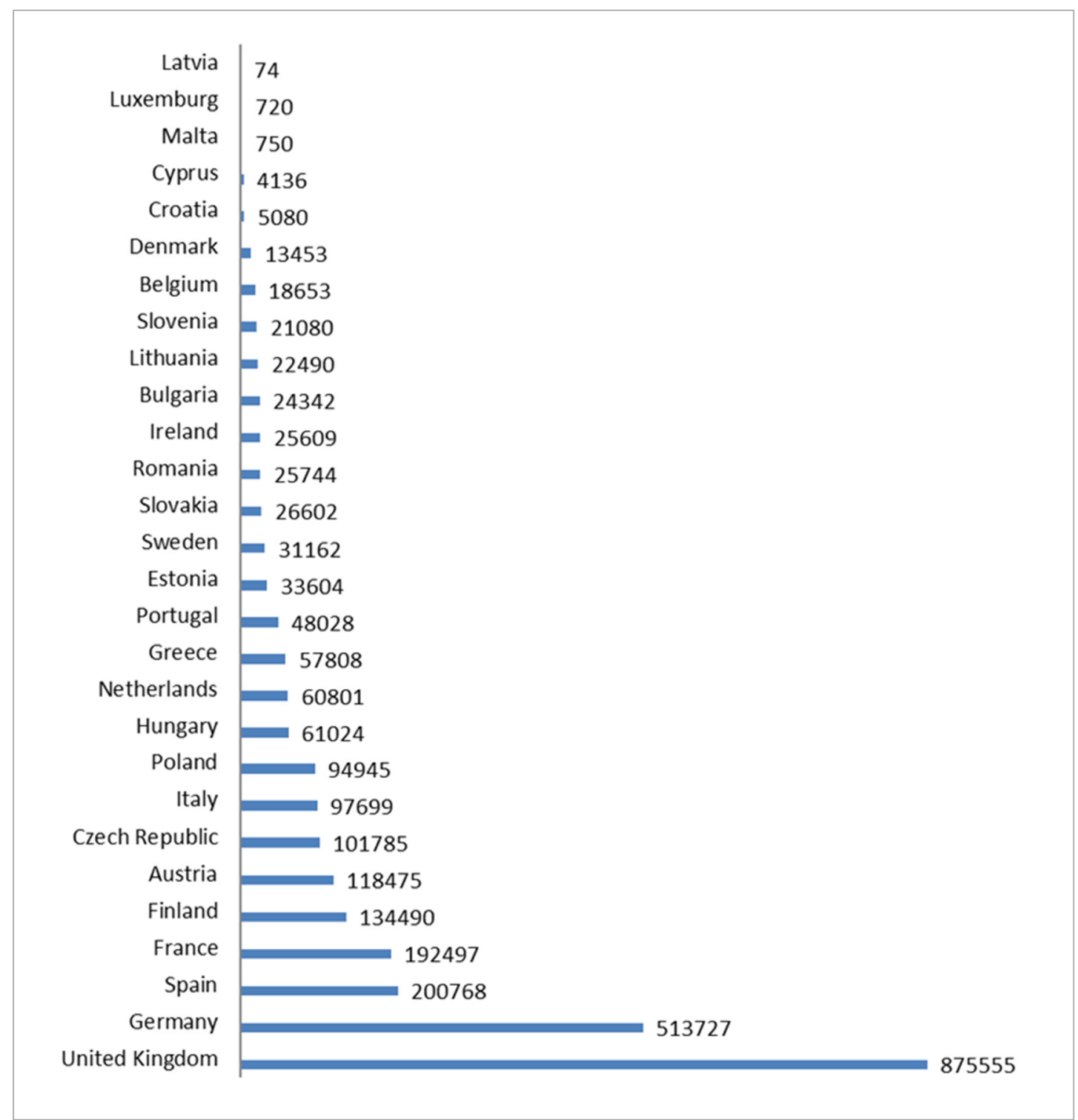

Figure 2

The size of the social economy in 28 European countries

Source: OECD, 2013

The problems that arise for such enterprises are still related to bureaucratic procedures, high taxes, poor management skills, non-innovative activities and low added-value created because of a lack of innovative technologies and decisions. SMEs also operate in rural areas. And the situation there is even more difficult because of a small market and lack of consumers. Family business is also related to SMEs, but the legal basis for it is not well developed in the country.

Therefore, from the legal economic criteria perspective, some preparations for appropriate classification of family farms have already been made. That is a step forward in Lithuanian agriculture making conditions more favourable for farmers and family householders.

Social environment. In Lithuania, the population declines faster than in any other EU country3. The emigration flows from the country have already been mentioned. Despite economic reasons, said social problems could be the cause of such a situation. For 25 years the corruption index in Lithuania remained almost at the same level (approximately 55) 4 . People do not trust their public

3 see www.stat.gov.lt 
and governmental institutions. The reasons are obvious. Public management stayed at quite a poor level, that caused ineffective solutions from the strategic to the tactical levels. That always disappoints people because it creates more social problems, such as insufficient education system, medical services, tax system ineffectiveness, inequality and overall disappointment in the development of the country. Lithuania has the biggest number of suicides per country in the $\mathrm{EU}^{5}$. That leads to very sad social climate and critical thinking about what is happening in the country. Even in the world Lithuania is in the $8^{\text {th }}$ place after such countries as Sri Lanka, Guyana, Kazakh$\operatorname{stan}^{6}$. Those facts are even more disappointing when considering Lithuania's place in the overall context of the world. Responsibility of the public sector is a quite complicated issue because of the complexity of public organisations and institutions, variety of their functions. Today responsibility of public organisations has a lot in common with CSR as much as some business philosophy and management principles are addapted for implementing social responsibility. In this case, public organisations' responsibility is analysed through accountability and publicity implementation taking into consideration social marketing as a helpful tool (Greblikaite, Tamuliene, 2016). In rural areas, social climate is worse than in the towns because of higher unemployment, poverty, social exclusion, closing schools. The situation is even more different in the so-called thirdworld countries where poverty is high (but EU countries are also not immune to it - about 20 percent of population live below the poverty line in such countries as Lithuania and Latvia (Eurostat data)). Therefore, social entrepreneurs must create novel business models and organisational structures, and unique strategies for brokering between very limited, disparate and often dynamic resources to create social value (Konda et al., 2015). The difference in economic development of the countries does not deny the fact that social entrepreneurship is powerful tool for synergy of different regions and environments especially seeking to diminish poverty and social exclusion.

The existing problems in Lithuanian rural areas must be solved by public institutions, but on the other hand that is also an area for social entrepreneurs and their actions. Every social problem could become a great business plan with a positive solution. That is why social entrepreneurship could be a tool for improving not only the economic but also the social situation.

Social enterprises in Lithuania
Lithuanian social enterprises development trends at the end of 2016 were as following: there were 158 social enterprises, of which 66 - social enterprises, employing people with disabilities. The number of social enterprises in the years 2006-2016 shows increasing trends in Lithuania. In 2011 the number of social enterprises decreased till 36, but after that the number of social enterprises in Lithuania was increasing progressively. During the period 2006-2016 number of social enterprises employing people with disabilities could be characterized by continuous growth as employers had the opportunity to employ people with disabilities and use of the various categories of State assistance. In 2016 the number of disability social enterprises reached 97 (see Figure 3). The increasing number of social enterprises shows that employment conditions, social integration and training of social skills are getting better.

63,3 percent of the main activities of all social enterprises are related to the provision of various services (consultancy, catering, computer maintenance, cleaning services, printing services, etc.). The main activities of the majority of social service enterprises are cleaning services (25\%), consulting (10\%), packaging (9\%), auxiliary construction and finishing (7\%), health promotion (6\%) (see Figure 3 ). $67,83 \%$ of employers working in social enterprises are employed in social service enterprises (the majority of employed people are with special needs or have limited work capacity).

4 see www.transparencyinternational.org

5 see http://ec.europa.eu/eurostat/web/products-eurostat-news/-/DDN-20170517-1?inheritRedirect=true\&redirect $=\% 2$ Feurostat $\% 2 F$

6 see https://en.wikipedia.org/wiki/List_of_countries_by_suicide_rate 


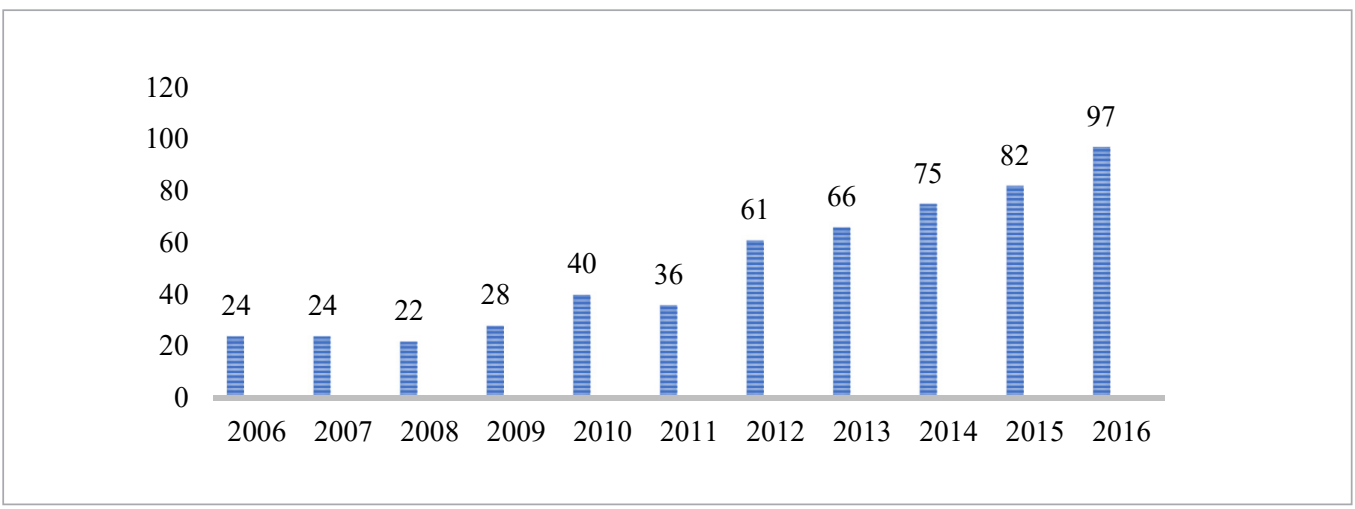

Figure 3

Dynamics of number of social enterprises in Lithuania

Source: Created by the author according to Lithuania labour exchange.

$36,7 \%$ of social enterprises work is related to production (sewing and textile products, food products, furniture, paper products, etc.). The major part of manufacturing social enterprises is mainly related to sewing and textiles (17\%), furniture production (12\%), food production (10\%), paper production (5\%) (see Figure.4). 32,17\% of people working in social enterprises are employed in manufacturing social enterprises. The fact that most social enterprises operate in the field of provision of services is the reason that most people with disabilities can't work physically or are with a big possibility for risk.

Since the adoption of the Law in 2004, the number of registered social enterprises in Lithuania increased five times and the number of their supported employees - seven times (see Figure 5). Over 10-year period state subsidies increased more than 20 times, from 0.57 million Eur in 2004 to more than 11.58 million Eur planned in 2014. Since 2008 large part of these subsidies are allocated from the ESF funds. It is forecasted that in 3 years number of social enterprises (as per Law on

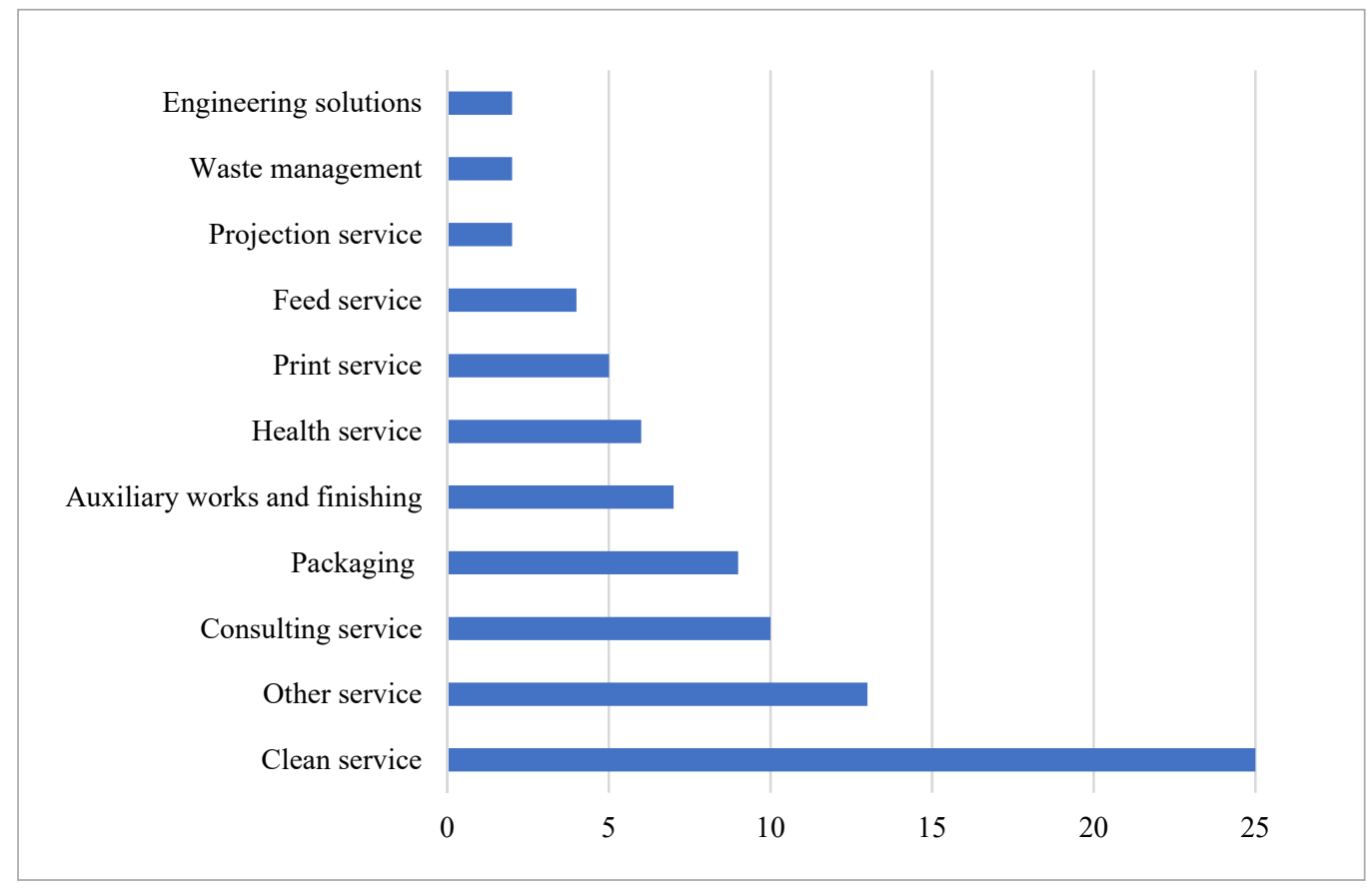

Figure 4

Social enterprices distibution by working in service activities

Source: Created by the author according to Lithuanian Labour Exchange. 
Figure 5

Social enterprises distribution by manufacturing activities

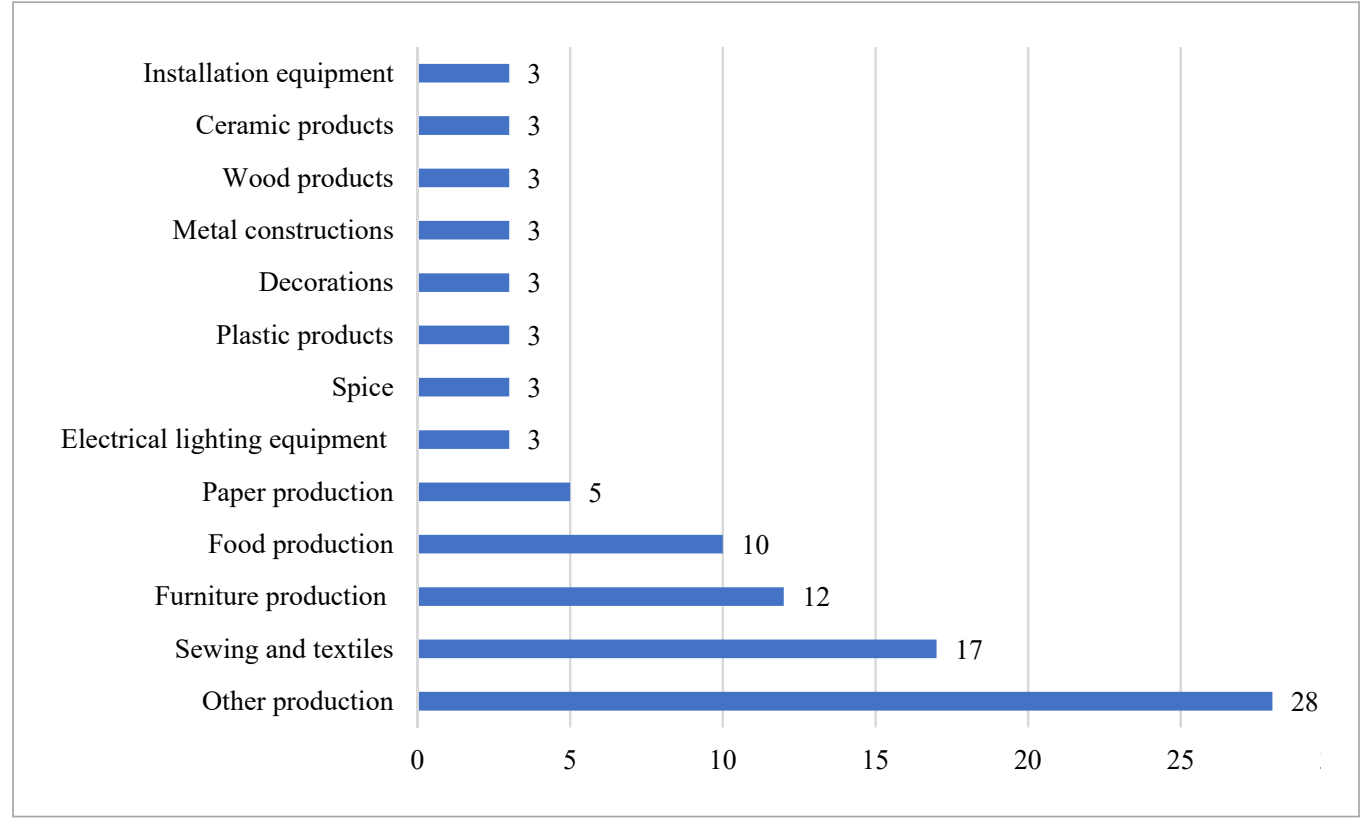

Source: Created by the author according to Lithuanian Labour Exchange.

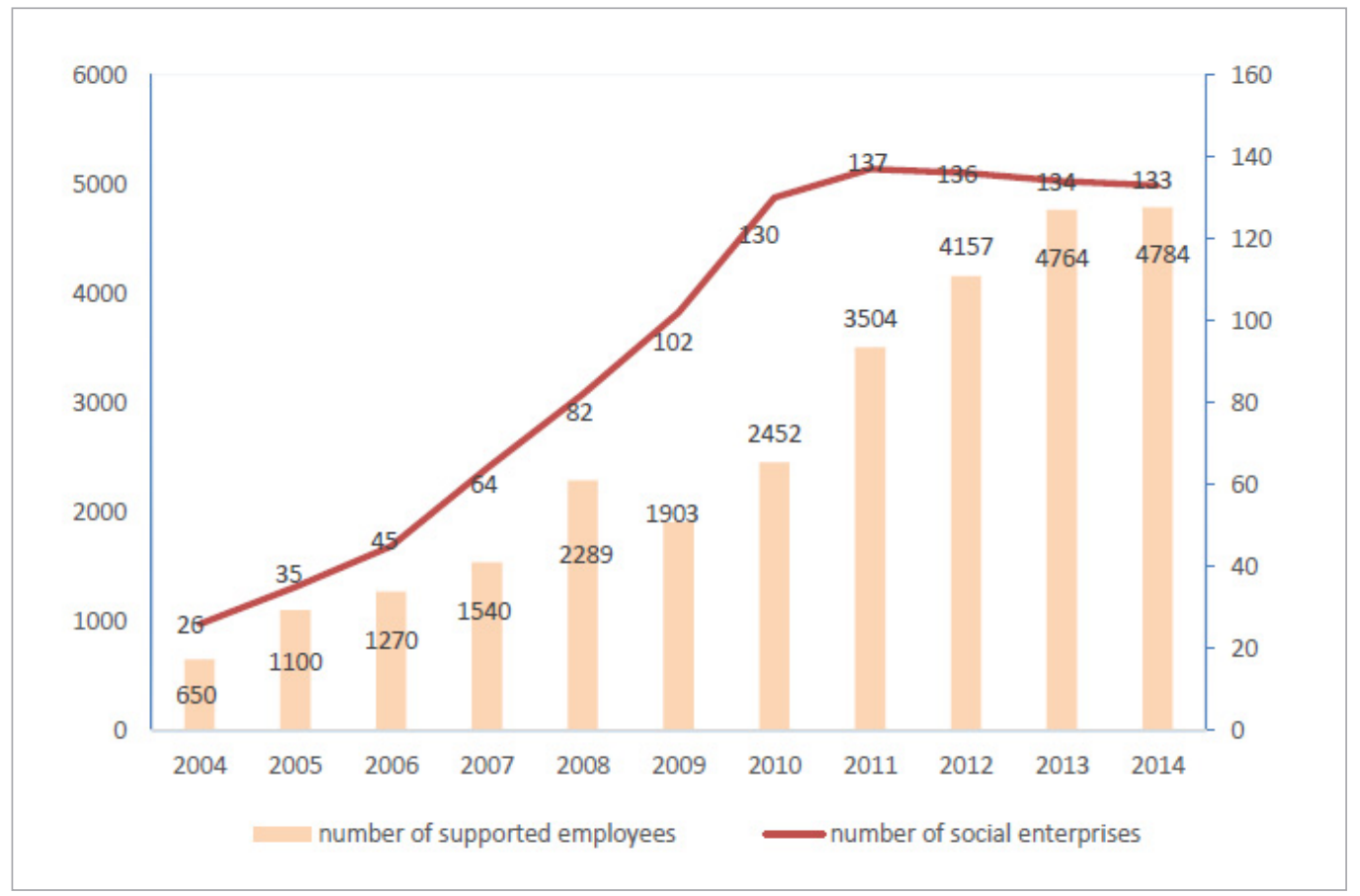

Sources: Lithuanian Labour Exchange, 2016; Šcerbickaitè, Moskvina, 2013.

Social Enterprises) will not increase significantly (5-6 start-ups per year). However, number of the disabled employees could reach 7000. Thus, demand for state subsidies could reach about $€ 18.83$ million EUR or around 1.5 times more than in 2014 and is likely to constantly grow further.

The fulfilled analysis of the social enterprises activity in Lithuania presents the imporving situation but also discloses the problems and challenges for such business. 
Boost of social economy in the EU countries disclosed a lot of possibilities, but otherwise it has been a challenge for some countries, including Lithuania. Social enterprises are supported by state implementing social and economic policy. But despite potential they could expose, especially in problematic rural areas, the situation remains complicated as environment analysis revealed. The difficulties remain in legal, economic, and social environment for prosperous development of social enterprises. Lack of appropirate legislation, tax burden, bureaucracy, financial dificultires in SMEs, social climate in the country are just some of them. The latest data expose interest of business to become social, especially in rural areas because their situation is more difficult than in towns in terms of unemployment and activity development. The further research in the theme could be directed to business actors attitude and intentions to develop social business.

Amin, A., Cameron, A. and Hudson, R. (2002). Placing the Social Economy. London: Routledge.

Arpinte, D., Cace, S., Cojocaru, S. (2010). Social economy in Romania. Preliminary Approach. Revista de cercetare si interventie sociala/Review of Research and Social Intervantion: 31, 64-79.

Azmat, F; Samaratunge, R. (2013). Exploring Customer Loyalty at Bottom of the Pyramid in South Asia. Social Responsibility Journal: 9 (3), 379-94. https://doi.org/10.1108/SRJ-09-2011-0077

Bidet, E. (1997) L'e'conomie sociale. Paris: Le Monde-Editions.

Borzaga, C., Santuari, A. (2003). New Trends in the Non-profit Sector in Europe: the Emergence of Social Entrepreneurship. In OECD (ed.), The Non-profit Sector in a Changing Economy (pp. 31-59). Paris: OECD.

Browne, P. L. (1997). The two faces of the social economy. Paper presented at the Eighth Conference of Canadian Welfare Policy, University of Regina, Saskatchewan, June.

Cace, S., Arpinte, D., Theotokatos, H., Koumalatsou, E. (2010). The Social Economy in the European Union, Calitatea vietii, XXI, no. 1-2, 137-160.

Chaves, R. (2015). The Weight of the Social Economy. Presented at the workshop de la Presidence du Conseil de lÚnion Europeenne "Establishing Satellite Accounts for the Social Economy", Luxembourg, October.

Concise (2003). The Contribution of Social Capital in the Social Economy to Local Economic Development in Western Europe, Final Report.

Connelly, S., Markey, S., Roseland, M. (2011). Briding sustainability and the social economy: Achieving community transformation through local food initiatives. Critical Social Policy: 31(2), 308-324. https://doi.org/10.1177/0261018310396040

Defourny, J., Develtere, P. (1999). The Social Economy: the Worldwide Making of a Third Sector. Centre D'economie Sociale, University of Liege.
Dunoyer, C. (1830). Nouveau traite' d'e'conomie sociale, ou simple exposition des causes sous l'influence desquelles les hommes parviennenta ' user de leurs forces avec le plus de LIBERTE', c'est-a '-dire avec le plus FACILITE'et de PUISSANCE. Paris: Sautelet.

EC, (2014). Social enterprises: report presents first comparative overview. Available at: http:// ec.europa.eu/social/ main.jsp?langld=en\&catld =89 \&newsld=2149.

EC, 2014. A map of social enterprises and their eco-systems in Europe. Country Report: Lithuania.

ECOTEC, (2000). Third System and Employment: Final Report of External Evaluation. Brussels: ECOTEC. Evans, M., Syrett, S. (2007). Generating Social Capital?: The Social Economy and Local Economic Development. European Urban and Regional Studies: 14(1), 55-74. https://doi. org/10.1177/0969776407072664

Greblikaitè, J; Tamulienè, V. (2016). Responsibility of public sector: CSR implementation through social marketing, Публічне управління та адміністрування в умовах інформаційного суспільства: вітчизняний і зарубіжний досвід: монографія. Запоріжжя: РВВ ЗДІА: 521-540.

Greblikaitè, J; Rakštys, R. (2016). Socialaus verslumo aplinka Lietuvoje. Vadyba, kooperacija, inovacijos. Tarptautinès mokslinès-praktinès konferencijos medžiaga, (International Conference, Book of Abstracts): 16-17.

Konda, I; Stare, J; Rodica, B. (2015). Social challenges are opportunities or sustainable development: tracing impacts of social entrepreneurship through innovations and value creation. Ekonomske teme: 53 (2), 215-233. https://doi.org/10.1515/ethemes-2015-0012

Le ' Vesque, B., Malo, M.-C. and Girard, J.-P. (1999). L'ancienne et la nouvelle e'conomie sociale, in: J. Defourny, P. Develtere and B. Fonteneau (Eds)

Conclusions 
L'e 'conomie sociale au Nord et au Sud (pp. 195216). Paris: De Boeck\&Larcier.

Liger, Q., Stefan, M., Britton, J. (2016). Social Economy. European Union, European Parlament.

Lithuania Labour Exchange, Neigaliuju idarbinimo galimybiu studija, 2012.

LR Ūkio ministerija/ Lithuanian Ministry of Economy (2015). Socialinio verslo koncepcija/ The concept of social entrepreneurship. Available at http:// www.ukmin.lt/uploads/documents/Verslo\%20 aplinka/Smulkus\%20verslas/Socialinio_verslo_koncepcija_2015_\%C4\%AFsakymas.pdf. [Accessed 2 March 2017].

McMurtry, J. J. (2010). Living Economics: Canadian Perspectives on the Social Economy, Co-operatives, and Community Economic Development. Toronto: Emond Montgomery.

Molloy, A., McFeely, C., and Connolly, E. (1999). Building a Social Economy for the New Millennium. Derry: Guildhall Press/NICDA.

Moulaert, F., Ailenei, O. (2005). Social Economy, Third Sector and Solidarity Relations: A Conceptual Synthesis from History to Present. Urban Studies, 42(11), 2037-2053. https://doi. org/10.1080/00420980500279794

Ney, S; et al. (2014)/ Social entrepreneurs and social change: tracing impacts of social entrepreneurship through ideas, structures and practices. Journal Entrepreneurial Venturing: 6(1), 51-60. https:// doi.org/10.1504/IJEV.2014.059405
Pearce, J. (2003) Social Enterprise in Anytown OECD, Ed. byAntonella Noya and Emma Clarence, The Social Economy. Building inclusive economies 2007. Avilable at https://www.scribd.com/ document/93901305/OECD-the-Social-Economy-Building-Inclusive-Economies. London: Calouste Gulbenkian Foundation.

Smith, G. (2005). Green Citizenship and the Social Economy. Environmental Politics: 14(2), 273-289. https://doi.org/10.1080/09644010500055175

Social Economy Europe (2015). Social Economy. Available at: http://www.socialeconomy.eu.org/ social-economy

Šcerbickaite K., Moskvina J. (2013). Social entrepreneurship and other models to secure employment for those most in need (Croatia, 29-30 October 2013): Social Enterprises in Lithuania. Comments paper - Lithuania. Peer Review on social entrepreneurship, Croatia.

Topalov, C. (1999). Les 're'formateurs' et leurs re'seaux: enjeux d'un objet de recherche, in: $\mathrm{C}$. Topalov (Ed.) Laboratoires du nouveau sie 'cle: la ne'buleuse re'formatrice et ses re'seaux en France, 1880-1914, pp. 11-58. Paris: Editions de l'E' cole des Hautes E' tudes en Sciences Sociales.

Vaillancourt, Y. (2009). Social economy in the Co-construction of Public Policy. Annals of Public and Cooperative Economics: 80(2): 275-313. https://doi.org/10.1111/j.1467-8292.2009.00387.x

\section{About the authors \\ GREBLIKAITE JOLITA \\ Assoc. Prof., PhD \\ Aleksandras \\ Stulginskis University Institute of Business and Rural Development Management \\ Fields of research interests \\ Social entrepreneurship, family business, social business in rural areas, young entrepreneurs \\ Address \\ Universiteto str. 10 Akademija, Kauno raj. Lithuania Tel. +37061644615}

\section{GERULAITIENE NERINGA \\ PhD candidate}

Kaunas University of Technology

\section{Fields of research interests}

Family business, dynamic managerial capabilities, innovations and entrepreneurship

\section{Address}

K. Donelaicio str. 73 Kaunas, Lithuania Tel. +37067226560

\section{ZIUKAITE ZIVILE}

\section{Master of Economics}

Aleksandras

Stulginskis University Institute of Business

and Rural Development Management

\section{Fields of research interests}

Social entrepreneurship, family business, social business in rural areas

\section{Address}

Universiteto str. 10 Akademija, Kauno raj. Lithuania Tel. +37060200946
GARCIAMACHADO JUAN J.

Professor of Finance

University of Huelva

Fields of research interests

Econometrics, risk assesment and management, agriculture, finance

\section{Address}

Plaza de la Merced, 11 21002 Huelva, Spain 